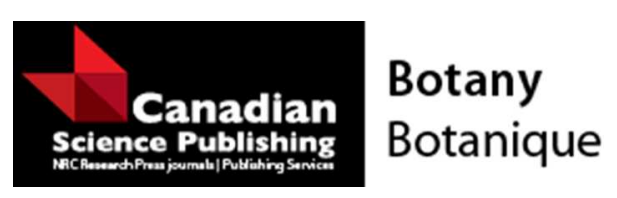

\title{
The Death Cap mushroom (Amanita phalloides) moves to a native tree in Victoria, British Columbia
}

\begin{tabular}{|r|l|}
\hline Journal: & Botany \\
\hline Manuscript ID & cjb-2016-0183.R2 \\
\hline Manuscript Type: & Note \\
\hline Complete List of Authors: & $\begin{array}{l}\text { Berch, Shannon; British Columbia Ministry of Environment } \\
\text { Kroeger, Paul; no institution } \\
\text { Finston, Terrie; University of Victoria }\end{array}$ \\
\hline Keyword: & $\begin{array}{l}\text { ectomycorrhiza, Death cap mushroom, Amanita phalloides, Quercus } \\
\text { garryana }\end{array}$ \\
\hline \multicolumn{2}{|c}{} \\
\hline
\end{tabular}

\section{SCHOLARONE ${ }^{\text {m }}$}

Manuscripts 
The Death Cap mushroom (Amanita phalloides) moves to a native tree in Victoria, British

\section{Columbia}

Shannon M. Berch, British Columbia Ministry of Environment, North Road Lab, Victoria BC V8W 9C4, Canada, shannon.berch@gov.bc.ca

Paul Kroeger, 395 East 40th Avenue, Vancouver, BC V5W 1M1, Canada, kroeger.paul@gmail.com

Terrie Finston, MycoLogic Inc., c/o Biology Dept., University of Victoria, P.O. Box 1700, STN CSC, Victoria, BC V8W 2Y2, Canada, tfinston@uvic.ca

Corresponding author: Shannon M. Berch 


\begin{abstract}
Amanita phalloides (Vaill. ex Fr.) Link, the Death Cap mushroom, is an invasive ectomycorrhizal fungus in North America that was inadvertently introduced from Europe. Death Cap mushrooms are highly toxic and have caused three recorded poisonings in British Columbia, including one recent death. In British Columbia, these mushrooms fruit mostly in urban environments in the greater Vancouver and Victoria areas under planted exotic broadleaf trees. In California, A. phalloides was demonstrated to also form ectomycorrhizas with a native oak species. Here we report that A. phalloides forms ectomycorrhizas with Quercus garryana, BC's only native species of oak, and can fruit in association with this tree host. If Death Cap mushrooms spread in Q. garryana habitat, the risk for serious mushroom poisoning will increase and mushroom harvesters, the medical community, and park managers need to be aware of this increased risk.

Key words: ectomycorrhiza, death cap mushroom, Amanita phalloides, Quercus garryana
\end{abstract}

\title{
Introduction
}

Amanita phalloides, the Death Cap mushroom, is the only known invasive ectomycorrhizal fungus in North America, having been introduced to North America from Europe many decades ago likely on the roots of imported plants (Pringle et al. 2009). The Death Cap mushroom contains toxins that target the liver primarily but other organs such as the kidneys are also affected. Symptoms usually appear after a lag period of 6-12 hours (Kent and Willis 1997) and may include nausea and vomiting followed by jaundice, seizures, and coma, culminating in death; the mortality rate is $10-30 \%$ (Garcia et al. 2015). Because of its toxicity, 
the Death Cap mushroom has been the focus of concern for mycological and medical communities.

The earliest confirmed report of $A$. phalloides on the west coast of North America appears to have been in 1938 on the grounds of the Del Monte Hotel in Monterey, California (CA). Since then, A. phalloides has been collected from Los Angeles, CA, north to Vancouver, British Columbia (BC) (Wolfe et al. 2010) and the most common host in California is the endemic Quercus agrifolia Nee (Wolfe and Pringle 2012). On the east coast of North America, the first confirmed collections of Death Cap were made in the 1970s (Tanghe and Simons 1973, Wolfe et al. 2010) and most confirmed collections are from planted or disturbed stands of conifers rather than from native forests (Wolfe and Pringle 2012). These observations have led to the hypothesis that $A$. phalloides was introduced to North America more than once and that the different introductions involved genotypes adapted to either oaks or conifers (Tanghe and Simons 1973, Saylor 1984, Wolfe and Pringle 2012).

The first record of $A$. phalloides growing in Canada is a British Columbia collection of a single fruitbody (UBC F13925) found on October 13, 1997 in a grove of large Castanea sativa Mill. (European sweet chestnut) trees in Lake Errock area near Mission BC. The second Canadian record of A. phalloides (DAVFP No. 25413 and UBC F14647) was collected on October 24, 1998 under a large ornamental Fagus sylvatica L. (European beech) tree in the landscaped grounds of Government House, official residence of the Provincial Lieutenant Governor, in Victoria on southern Vancouver Island. On October 13, 2008 the first A. phalloides in Vancouver, BC were collected from under a Carpinus betulus L. (European hornbeam) street tree apparently planted by the city in the 1960s. The vast majority of subsequent collections of 
Death Cap mushrooms within the city of Vancouver have been under the "Fastigiata" cultivar of Carpinus betulus planted as street trees. By 2015 there were numerous records of $A$. phalloides from the south-western corner of British Columbia - in the Fraser Valley, Vancouver and its neighbouring municipalities in the Fraser Delta, around Victoria on southern Vancouver Island, and Galiano Island. Almost all of the 72 BC Amanita phalloides locations recorded in the UBC Herbarium have been under non-native broadleaf tree species. However, twice in Victoria, $A$. phalloides has been reported to fruit either where exotic trees and native Quercus garryana Douglas ex Hook. (Garry oak) grow together (DAVFP No. 29324) or where Garry oaks grow alone (UBC F26423). No collections from BC have been associated with conifers.

The first recorded Death Cap poisoning in Canada occurred on August 17, 2003 in Victoria, BC (Friesen et al. 2005) when a 46-year-old man mistook Death Cap buttons for puffballs and the second recorded poisoning occurred on September 6, 2008 in Vancouver involving a 68 year old woman who believed she had found paddy-straw mushrooms, a cultivated species popular in parts of Asia (BC Drug and Poison Information Centre, pers comm); both patients recovered after hospitalization. Tragically, in late October, 2016, a young boy died after ingesting Death Cap mushroom harvested from a residential street in Victoria (http://www.viha.ca/about_viha/news/news_releases/nr_death_poison_mushroom_12oct201 6.htm).

In October, 2015, fruiting bodies of $A$. phalloides were found in a Saanich, BC, location where no exotic trees were growing. Because almost all previous confirmed reports of $A$. phalloides in $\mathrm{BC}$ were associated with exotic host trees, this chance fruiting provided an opportunity to determine whether a native tree species was hosting the fungus. Association 
with a native tree species would establish this mushroom's status as a truly invasive species in $\mathrm{BC}$ and indicate the potential for spread of this highly toxic mushroom into non-anthropogenic habitats.

\section{Materials and methods}

On October 8, 2015 fruiting bodies of $A$. phalloides were collected (by SMB) from the North Road Lab in Saanich, BC (part of the British Columbia Corporate Services Sector for the Natural Resources, located at 4300 North Road). The mushrooms were fruiting next to the driveway and adjacent to a remnant forest stand of Pseudotsuga menziesii (Mirb.) Franco and Q. garryana (Fig. 1). This is the first time in the $20+$ years that SMB has worked at this location that this species has been observed to fruit. To confirm identification, fruit bodies were observed under the microscope and then dried as a voucher. The dried voucher was submitted for DNA sequencing (see below) and then deposited into the fungal collection DAVFP (DAVFP No. 29291).

At the same time an intact soil core was sampled from immediately below the fruiting bodies to a depth of $15 \mathrm{~cm}$. In the lab, the fine tree roots were gently washed from the soil and examined under the microscope. Fourteen individual fine root segments, each bearing multiple ectomycorrhizal root tips, were retrieved and each tip was individually observed for ectomycorrhiza (ECMs). Anatomical attributes of the ECMs suggested an angiosperm rather than coniferous affiliation, i.e. the Hartig net penetrated only the epidermis and the epidermal cells were radially elongated (Smith and Reid 2008). ECMs were sorted at 10-20x magnification into morphotypes and for each of the 14 fine root segments (labelled $1-14$ ), between one and 
six representative ECMs of the different morphotypes (labelled $a-f$, as needed) were placed individually into vials. For example, four ECM morphotypes were observed on fine root segment 1 , and were labelled $1 \mathrm{a}-1 \mathrm{~d}$. The vials were frozen at $-20 \mathrm{C}$ and a total of $36 \mathrm{ECM}$ tips were delivered to MycoLogic Inc. for sequencing.

To determine the identity of the plant host and ECMs, DNA was extracted from each of the 36 ectomycorrhizas. One or two representatives from each of the 14 root systems were sequenced for plant chloroplast DNA and all 36 samples were sequenced for fungal ITS DNA. Extraction of fungal and plant DNA from root tissue followed Berch and Bonito (2016), however, the bead-beating and centrifugation steps were carried out a total of six times, three times prior to and three times following the addition of $70 \mu \mathrm{L}$ of Prepman solution. The samples were then ground manually for 30 s with a mini Pellet Pestle (Sigma-Aldrich, Oakville, ON, Canada). In order to obtain DNA template for Q. garryana, leaves were sampled from a separate tree in Saanich, BC. Two to three $5 \times 5 \mathrm{~mm}$ pieces were ground in a mortar with $5 \mathrm{~mL}$ aliquots of liquid nitrogen, until the sample produced a fine powder. Plant DNA was extracted using the DNeasy Plant Mini Kit (Qiagen, Germantown, WI, USA) following the manufacturer's instructions.

Fungal ITS was amplified as described in Berch and Bonito (2016). Reverse primer ITS4 was used to amplify most samples however, in order to obtain sequences from all fungal specimens, three additional reverse primers were paired with the ITS1F forward primer: ITS4-B (Gardes and Bruns, 1993), LR1 (Vilgalys and Hester 1990) and the newly designed primer LRC42 (details provided on request to Terrie Finston). To obtain plant nucleotide sequences from the leaves and ECMs, the primers trnL-e and trnL-f were used to amplify an approximately $420 \mathrm{bp}$ 
region of non-coding chloroplast DNA (cpDNA), an intergenic spacer (IGS) region located between the $\operatorname{trnL}$ and $\operatorname{trnF}$ genes (Taberlet et al., 1991). The sporocarps of $A$. phalloides were amplified for ITS as above and for an approximately $900 \mathrm{bp}$ fragment of the nuclear ribosomal RNA large subunit (LSU) using primers LROR and LR5 (Vigalys and Hester 1990).

For ITS, each PCR reaction was performed as described in Berch and Bonito (2016), with the addition of $5 \mu \mathrm{g}$ BSA and 5\% DMSO. Further, 40 cycles were required and the annealing step was increased to $60 \mathrm{~s}$. Reaction conditions for chloroplast IGS were similar, except denaturation, annealing and extension steps were each increased to $60 \mathrm{~s}$. For the LSU, each PCR reaction was performed as described in Berch and Bonito (2016).

Amplified products (1-40 $\mathrm{ng} / \mu \mathrm{L})$ were sequenced in both directions, either by Eurofins MWG Operon (Operon, Huntsville, AL, USA) or the Plateforme de séquençage et de génotypage des génomes (Université Laval, Québec, QC, Canada), following purification using the Column Pure PCR Clean-up Kit (ABM, Richmond, BC, Canada), according to the manufacturer's instructions. Nucleotide sequences were edited and aligned using MEGA (ver. 6.0; Tamura et al., 2013). Fungal ITS and LSU sequences were identified through queries against GenBank with the BLASTN algorithm, and the chloroplast IGS sequences from ECMs were compared for similarity to the sequences we obtained from the separate Garry Oak specimen.

\section{Results}

Sporocarps (DAVFP No. 29291) were identified morphologically and molecularly (GenBank accession numbers KX449211 and KX449431 for ITS and LSU, respectively) as Amanita phalloides (Table 1). The plant host was identified morphologically as Q. garryana. 
Because no IGS sequences of this species were available on GenBank, leaf tissue from a separate tree of $Q$. garryana was sequenced to provide a reference sequence for the species (UVic herbarium voucher Berch01; GenBank accession number KX449213). Each root segment was identified morphologically (typical angiosperm ectomycorrhiza anatomy) and molecularly as Q. garryana (Table 1; GenBank accession numbers KX449214 - KX449229 for the 14 root segments). Ectomycorrhizas were sorted into six distinct morphotypes and six distinct molecular groups were detected, showing highly significant matches on GenBank to six fungal species (Table 1; GenBank accession numbers KX449174-KX449210). Nine of the ectomycorrhizas were confirmed to be $A$. phalloides (4d, 8a, 8b, 8c, 9a, 10a, 10b, 10c, 13a; Table 1).

\section{Discussion}

Since the first collection at Government House, Amanita phalloides has been found at additional sites in Victoria, including under various planted, non-native trees including Tilia species (Basswood or Linden) trees in the Uplands neighbourhood, under Carpinus betulus (European Hornbeam) trees near the Crystal Gardens, and under beech (Fagus sp.) and oaks including English oak (Quercus robur) along boulevards in Victoria.

The distribution of these collections may be explained by historical land-use practices. Richard Emil Layritz (1867-1954) was a pioneer nurseryman from Germany who established Layritz Nurseries in 1889 on Wilkinson Road outside of Victoria BC, in what is now the municipality of Saanich. According to Jakeman (2000), Layritz Nurseries were responsible for helping to make Victoria the 'City of Gardens' by supplying planting stock including trees for 
many parts of the city including Government House in 1906, Crystal Gardens in 1925, many homes in the Uplands during the post-1912 development of that neighbourhood, and along boulevards planted by the city. Some Layritz Nurseries catalogues are available through the Ethel Z. Bailey Horticultural Catalogue Collection, Cornell University. Beech, linden and oak are listed for sale in Layritz Nurseries catalogues from 1925, 1931, 1940, 1952(?), and 1959. The 1959 catalogue also lists hornbeam (pers. comm. Dorothy Ann Stiefel; Layritz Nursery Materials - A collection of nursery and seed catalogs published by the Layritz Nursery also known as Layritz Nurseries Ltd. from [1913]-1959).

The Layritz Nurseries on Wilkinson Road in Saanich was located on a property adjacent to the property on which the North Road Lab now sits and where Death Cap mushrooms were found fruiting in October, 2015. Aerial photos from 1926 and 1946 clearly show Layritz Nurseries plantings and land use around the site of the current North Road Lab (Figure 2). As early as 1926 , the site immediately adjacent to the collection location for A. phalloides (DAVFP No. 29291) was under agricultural use (possibly as a tree nursery or an orchard) and by 1946 although the orchard was gone, agricultural use continued. Throughout these decades and to the present, a patch of remnant native Douglas-fir and Garry oak forest has remained at the edge of which Death Cap mushrooms were collected in October, 2015. The land use history of this site may illustrate how a reservoir of an invasive ectomycorrhizal species could be established adjacent to agricultural lands used for commercial production of horticultural trees capable of hosting the mushroom, thus contributing to its further spread in urban environments. 
Given the proximity of the Layritz Nurseries and the North Road Lab and the correlation between where Death Cap mushrooms now fruit in Victoria and the locations where Layritz nursery trees were planted, it seems possible that the Death Cap mushrooms that now fruit in locations throughout the greater Victoria area find their origin in the Layritz Nurseries on Wilkinson Road. It would be interesting to determine whether A. phalloides originally arrived in Victoria on nursery stock imported from Europe or from elsewhere in North America, perhaps California.

As was suggested with earlier collections made under adjacent exotic trees and native Garry oak trees or under Garry oak alone (DAVFP No. 29324, UBC F26423), A. phalloides has moved to Garry oak. Thus, two native oaks of western North America have now been demonstrated to form ECMs with Amanita phalloides, Quercus agrifolia (Wolfe and Pringle 2012) and Quercus garryana. The known distributions of these two tree species overlap in the San Francisco area and from there Quercus agrifolia extends south to Mexico and Quercus garryana extends north to Canada (Fig. 3). Spread of this fungus within these two oak distributions would increase the chances of wild mushroom harvester poisonings. Based on this single report of ectomycorrhiza formation by Amanita phalloides on Quercus garryana, it is not possible to predict whether Death Cap mushroom will indeed spread in native Garry oak forests and savannahs or among isolated trees in urban environments. However the predictive climate suitability mapping for Amanita phalloides in North America carried out based on climate parameters from the native range of this fungus in Europe (Wolfe et al. 2010) indicated that much of south coastal BC is appropriate habitat. In eastern North America, A. phalloides has fruited with planted trees in Connecticut, Maryland, New Jersey, New York, and Pennsylvania 
(Wolfe et al. 2010) but there are no confirmed reports from eastern Canada (Gavin Kernaghan, David Malloch, Simona Margaritescu, Jean-Marc Moncalvo, Faye Murrin, Scott Redhead, pers. comm.). If habitat becomes more suitable with changing climate, perhaps this highly toxic mushroom will begin fruiting in eastern Canadian cities.

Until now, Death Cap mushrooms in BC have largely been found under non-native broadleaf tree species in urban or otherwise disturbed surroundings. Given how toxic Death Cap mushrooms are, how extensive the suitable habitat is, and the fact that we have now demonstrated that Amanita phalloides can form ECMs with our native BC oak, it would be prudent to advise mushroom clubs, the medical community, and park managers that Amanita phalloides could fruit in previously unexpected habitats.

\section{Acknowledgements}

Thanks to Oluna Ceska for confirming morphological identification of the mushrooms, MycoLogic Inc. for molecular analyses, Angus Christian, GeoBC, for assistance locating the 1946 air photo, Ryan Watson, University of Victoria libraries, for assistance in obtaining the high quality digital image of the 1926 air photo, staff at the Saanich Archives for help finding information on Layritz Nurseries, and Dorothy Ann Stiefel, Ethel Z. Bailey Horticultural Catalogue Collection, Cornell University, for providing information from Layritz Nursery catalogues.

\section{References}


Berch, S.M., and Bonito, G. 2016. Truffle diversity (Tuber, Tuberaceae) in British Columbia. Mycorrhiza 26: 587-594. doi:10.1007/s00572-016-0695-2.

Friesen M.S., Pringle, A., Callan, B., and Leathem, A. 2005. Amanita phalloides heads north. Conference Proceedings of the North American Congress of Clinical Toxicologists. (Case study of death cap poisoning in British Columbia, Canada.)

Garcia, J., Costa, V.M., Carvalho, A., Baptista, P., Guedes de Pinho, P., de Lourdes Bastos, M., and Carvalho, F. 2015. Amanita phalloides poisoning: Mechanisms of toxicity and treatment. Food Chem. Toxicol. 86: 41-55. doi:10.1016/j.fct.2015.09.008.

Gardes, M., and Bruns, T.D. 1993. ITS primers with enhanced specificity for basidiomycetes application to the identification of mycorrhizae and rusts. Mol. Ecol. 2: 113-118. doi:10.1111/j.1365-294X.1993.tb00005.x.

Jakeman, J.E. 2000. The history of Layritz Nurseries Limited. Saanich Archives, Victoria, B.C.

Kent, D.R., and Willis, G. 1997. Poison Management Manual. The BC Drug and Poison Information Centre.

Pringle, A., Adams, R.I., Cross, H.B., and Bruns, T.D. 2009. The ectomycorrhizal fungus Amanita phalloides was introduced and is expanding its range on the west coast of North America. Mol. Ecol. 18: 817-833. doi:10.1111/j.1365-294X.2008.04030.x.

Saylor, H.M. 1984. A. phalloides in California: This preliminary report suggests that it is a relative newcomer to the state. Mushroom Magazine Summer 1984, 40-42.

Smith, S.E., and Read, D.J. 2008. Mycorrhizal Symbiosis, $3^{\text {rd }}$ edition. Academic Press. Pp. 234235. 
Taberlet, P., Gielly, L., Pautou, G., and Bouvet, J. 1991. Universal primers for amplification of three non-coding regions of chloroplast DNA. Plant Mol. Biol. 17: 1105-1109. doi:10.1007/bf00037152.

Tamura K., Stecher, G., Peterson, D., Filipski, A., and Kumar, S. 2013. MEGA6: Molecular Evolutionary Genetics Analysis (ver. 6.0). Mol. Biol. Evol. 30: 2725-2729. doi:10.1093/molbev/mst197.

Tanghe, L.J., and Simons, D. M. 1973. Amanita phalloides in eastern United States. Mycologia 65: 99-108. doi:10.2307/3757790.

Vilgalys, R., and Hester. M. 1990. Rapid genetic identification and mapping of enzymatically amplified ribosomal DNA from several Cryptococcus species. J. Bacteriol. 172: 42384246. doi: 0021-9193/90/084238-09\$02.00/0.

Wolfe, B.E., Richard, F., Cross, H.B., and Pringle, A. 2010. Distribution and abundance of the introduced ectomycorrhizal fungus Amanita phalloides in North America. New Phytol. 185: 803-816. Doi:10.1111/j.1469-8137.2009.03097.x.

Wolfe, B.E, and Pringle, A. 2012. Geographically structured host specificity is caused by the range expansions and host shifts of a symbiotic fungus. ISME J. 6: 745-755. Doi:10.1038/ismej.2011.155. 
Table 1. Highly significant Genbank ITS matches (except where indicated) for fungal taxa detected from sporocarps and from 36 samples of ectomycorrhizas (labelled a - f) on 14 root systems (labelled 1 - 14) from Quercus garryana.

\begin{tabular}{|c|c|c|c|}
\hline Taxon & $\begin{array}{l}\text { GenBank } \\
\text { accession } \\
\text { number } \\
\end{array}$ & Fungal collection or sample number & $\%$ similarity \\
\hline & & Sporocarps & \\
\hline $\begin{array}{l}\text { Amanita phalloides } \\
\text { ITS } \\
\text { LSU }\end{array}$ & $\begin{array}{l}\text { EU909442 } \\
\text { AY380359 }\end{array}$ & Berch 0167 (DAVFP No. 29291) & $\begin{array}{l}100 \\
99\end{array}$ \\
\hline & & Ectomycorrhizas & \\
\hline Amanita phalloides & EU909442 & $4 d, 8 a^{3}, 8 b^{3}, 8 c, 9 a, 10 a^{1}, 10 b, 10 c, 13 a$ & $99-100$ \\
\hline Cenococcum geophilum & AY112935 & $1 b^{2}, 6 a, 12 d$ & 99 \\
\hline Hebeloma sacchariolens & HF678207 & $1 c, 1 d, 6 d, 6 e^{3}, 12 a, 12 c^{1}, 14 a^{3}$ & 98-99 \\
\hline Russula cerolens & HQ604834 & $\begin{array}{l}2 a^{3}, 2 b, 2 c^{3}, 4 a, 4 b, 4 c, 4 e, 4 f, 5 a, 6 b, 6 c, \\
11 a^{3}, 12 b^{1}, 13 b, 14 b^{3}\end{array}$ & $99-100$ \\
\hline Tomentella sp. & EU726329 & $1 a, 3 a$ & 98 \\
\hline \multirow[t]{2}{*}{ Tuber beyerlei } & HM485408 & $7 a^{2}$ & 99 \\
\hline & & Plant host - leaves & \\
\hline \multirow[t]{2}{*}{ Quercus garryana } & $\left(\mathrm{KX} 449213^{*}\right)$ & UVic herbarium Berch01 & $*$ \\
\hline & & Plant host - ectomycorrhizas & \\
\hline Quercus garryana & KX449213 & $\begin{array}{l}1 a, 1 c, 2 a, 2 b, 3 a, 4 e, 5 a, 6 b, 7 a, 8 b, 9 a \\
10 a, 11 a, 12 d, 13 a, 14 b\end{array}$ & 100 \\
\hline
\end{tabular}

* Reference sequence we provided to GenBank.

${ }^{1,2,3}$ Reverse primer $=$ ITS4 except where noted: 1=ITS4-B, 2=LR1, 3=LRC42. 
Figure 1. Amanita phalloides fruiting at North Road Lab in Saanich BC. a. Mushroom adjacent to driveway (star = driveway; arrow $=$ A. phalloides mushroom cap). b. Mushroom with base somewhat excavated revealing volva. c. Closest forest remnant with Douglas-fir (white arrows), Garry oak (black arrows), and location of $A$. phalloides mushrooms (star).

Figure 2. Air photos of Layritz Nurseries and location of 2015 Death Cap fruiting in Saanich, B.C. a. Composite 1926 air photo showing location of October, 2015 collection site (white star) and the Layritz Nurseries office building (black star) amidst nursery beds. Distance between stars = $0.75 \mathrm{~km}$. b. Close-up of 1926 air photo showing possible tree plantation next to 2015 collection site (star). c. 1946 air photo showing open field next to 2015 collection site (star).

Figure 3. Map showing distribution of Quercus garryana and Quercus agrifolia. Created using separate distribution maps from Wikipedia. 

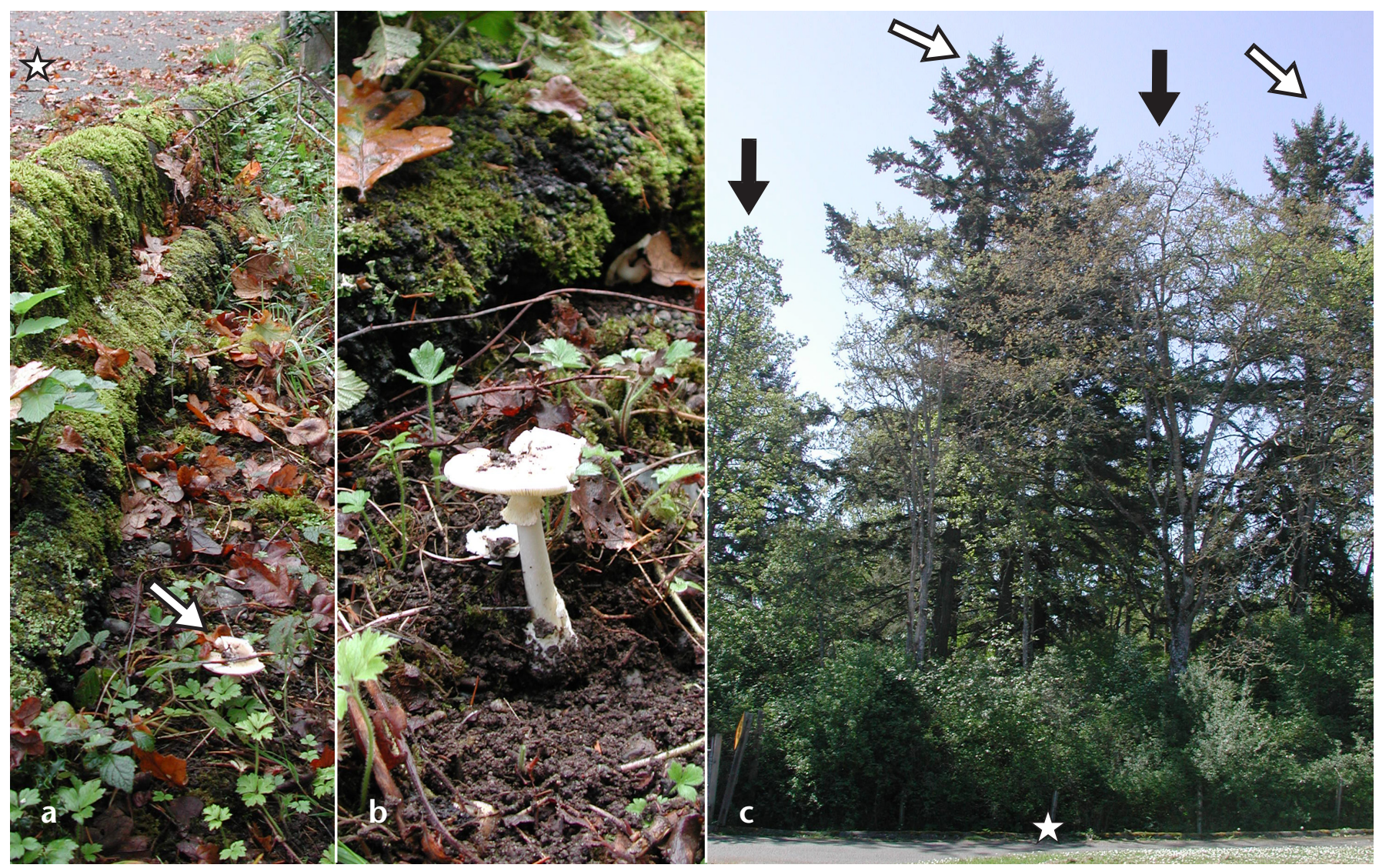

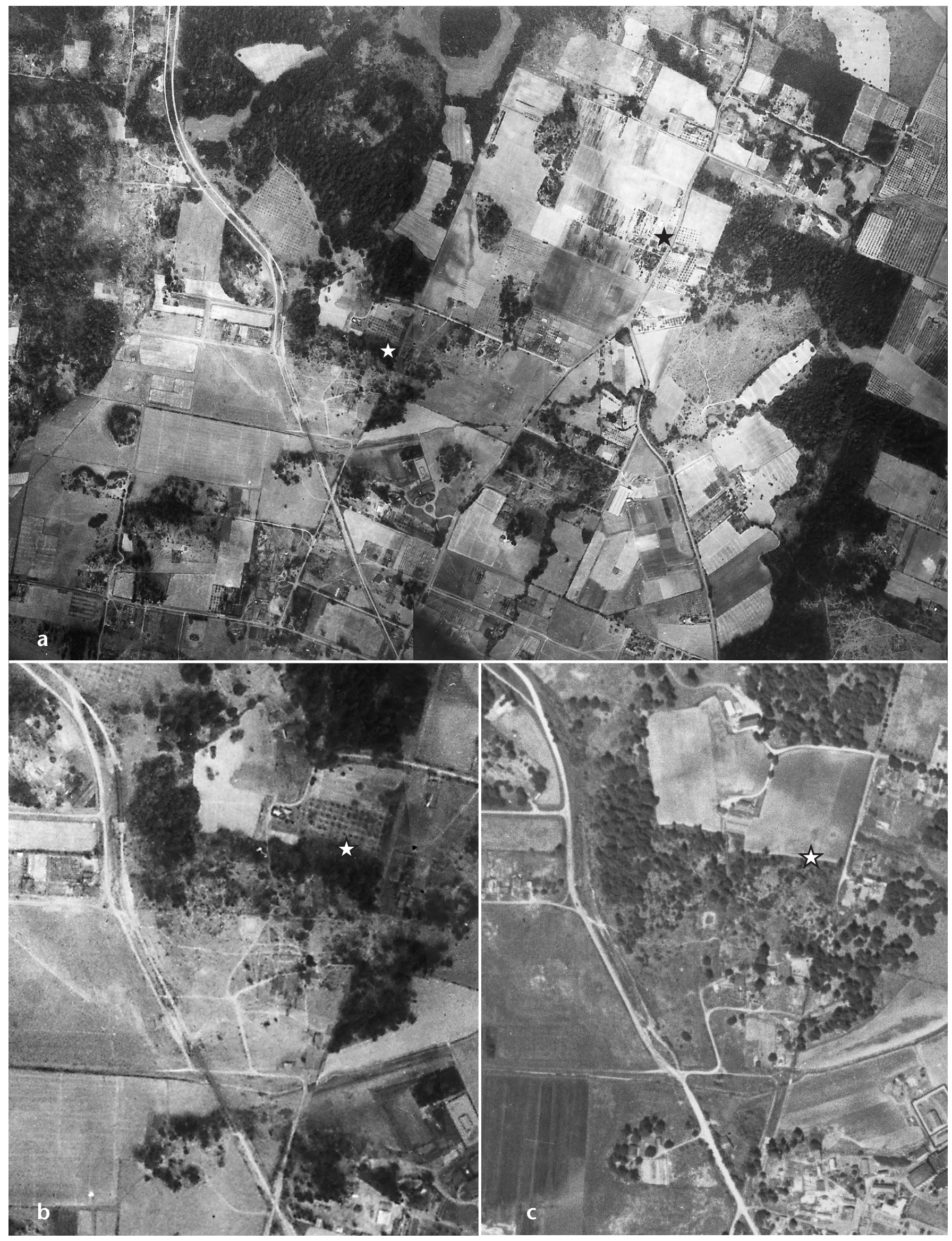


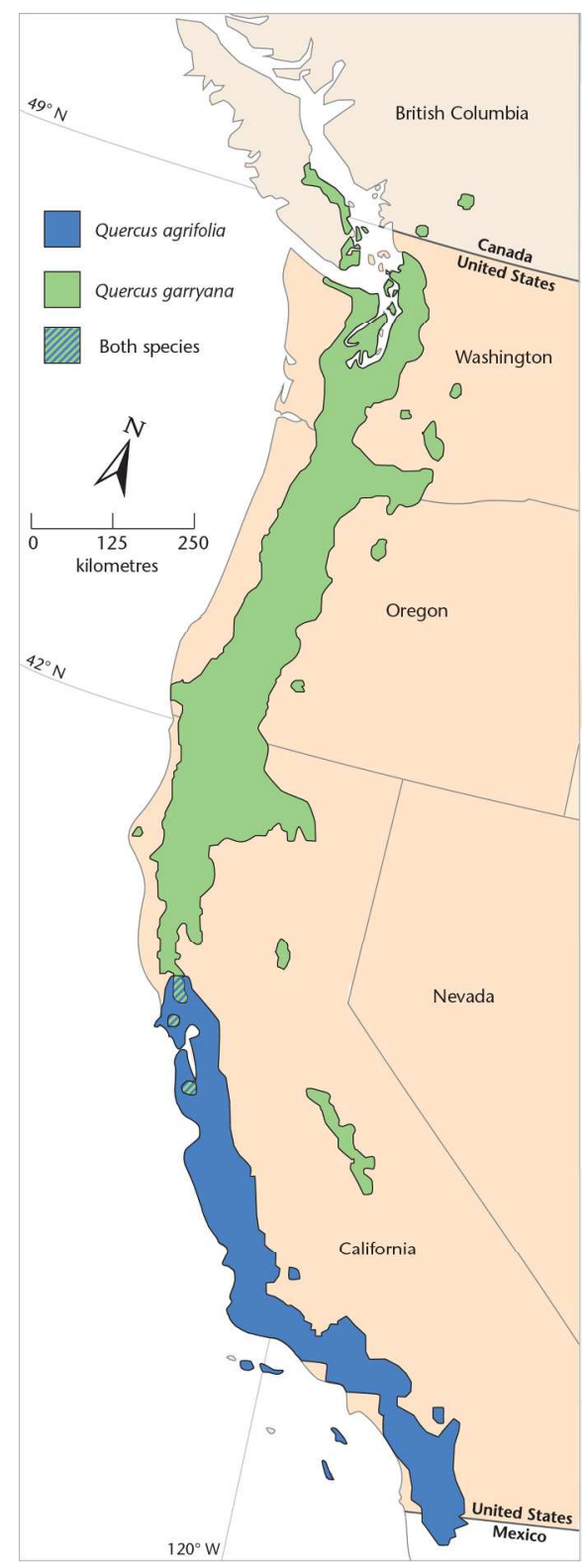

Figure 3. Map showing distribution of Quercus garryana and Quercus agrifolia. Created using separate distribution maps from Wikipedia.

$86 \times 237 \mathrm{~mm}(300 \times 300 \mathrm{DPI})$ 